\title{
The strategic use of historical narratives: a theoretical framework
}

History has long been recognized as a strategic and organizational resource. However, until recently, the advantage conferred by history was attributed to a firm's ability to accumulate heterogeneous resources or develop opaque practices. In contrast, we argue that the advantage history confers on organizations is based on understanding when the knowledge of the past is referenced and the reasons why it is strategically communicated. We argue that managers package this knowledge in historical narratives to address particular organizational concerns and audiences. As well, we show that different historical narratives are produced with the goal of achieving different organizational outcomes. The success of an organization is thus dependent on the ability of its managers to skilfully develop historical narratives that create a strategic advantage.

Keywords: organizational past; organizational history; historical narratives; rhetorical history; legitimacy; authenticity; identity; organizational culture; strategic advantage.

\section{Introduction}

There is an awareness of the importance of historical narratives within management and organizational history ${ }^{1}$. Yet, arguably, most research in business history has focused on the production of historical narratives about managers and organizations to understand the past and the effects it might have on the present. This can be seen in both the approach taken by realist business historians, such as Alfred Chandler $\mathrm{Jr}^{2}{ }^{2}$, and in some of the more recent cultural approaches to business history ${ }^{3}$. In contrast to these two approaches we assert that there is a third approach to business history that does not focus on historical narratives that are told about managers and organizations. Instead, it investigates how the past might provide organizations with a strategic advantage because of the way historical narratives are appropriated, mobilized and used, in the present, by managers and organizations ${ }^{4}$. In other words, the third approach to business history is concerned with how history is used as a strategic resource ${ }^{5}$.

This approach to business history is not particularly new nor is it surprising. The value of an organization's unique history has been noted and discussed in the strategy and management literatures over the past 30 years $^{6}$. There have been discussions about the 
historical advantage provided by key geographic locations ${ }^{7}$, the contents and operation of an organization's archives ${ }^{8}$, the architecture of the firm ${ }^{9}$, and the rhetorical construction of the organization's past deeds ${ }^{10}$. Moreover, there is an understanding that many of these aspects of an organization's past can be leveraged and used so that managers can meet and exceed their strategic ${ }^{11}$ and organizational ${ }^{12}$ goals. And although some of these studies have identified history as an organizational and strategic resource most, except for some notable exceptions ${ }^{13}$ have assumed that an organization's history is the same as the organization's past. That is, an organization's history is a strategic asset only because no other firm has experienced similar past events ${ }^{14}$. Yet, if we are to take seriously the assertion that history is a resource, then we need a more nuanced understanding of this third approach. To address this issue we shift the debate away from descriptions about managers and organizations and how the past accumulates and creates strategic advantages/disadvantages. We focus, instead, on when narrative elements of organization history can be used and why they might be used strategically.

Our discussion of historical narratives as organizational resources aims to provide preliminary answers to two main questions. First, we identify the circumstances under which managers might appeal to historical narratives when they could use many other kinds of narratives to construct a strategic advantage. In particular, drawing on history offers a way to build a common interpretation of events ${ }^{15}$ and to connect the organization to a shared collective past ${ }^{16}$. Organizational historical narratives are based on the idea of an existing past shared with individuals and groups as well as with broader collective arrangements. Through history-telling managers can enhance their stakeholder's connection to the organization by emphasizing the association it has with, for example, the nation-state, 
society or important events and occurrences with the organization. History-telling also provides a temporal structure to which individuals and groups can identify to make sense of their own personal and collective histories.

Second, we discuss the uses managers have for different historical narratives. We posit that the main reason why managers develop historical narratives is to achieve certain strategic outcomes. Managers can use historical narratives as a way to manage changes in their internal and external environment ${ }^{17}$. In addition, they might be proactive and engage with history to produce changes in the organizational environment ${ }^{18}$. To produce or to adapt to these changes, managers target different organizational outcomes, such as developing the organization's culture $^{19}$, building identity ${ }^{20}$, promoting authenticity ${ }^{21}$, and/or enhancing legitimacy $^{22}$. To achieve these outcomes we expect managers to produce different historical narratives depending on the organization's strategic purposes and the audiences they want to address. Thus, the value of a historical narrative as a resource is dependent on the ability of the manager to develop an appealing historical narrative that might be used to achieve the organization's intent while addressing its primary audience ${ }^{23}$.

The paper begins with a brief overview of how history has been discussed in the business history and organization studies literatures with a focus on the use of historical narratives as organizational resources. We then move to a discussion of the circumstances when historical narratives are developed and the rhetorical purpose of historical narratives. Next, our focus shifts to the four main strategic outcomes of historical narratives. We theorize when managers are more likely to develop different historical narratives depending on how they want to manage and address a specific organizational outcome. We conclude 
by speculating about the possible future directions of our research by identifying different avenues for studying historical narratives as organizational resources.

\section{History as a resource}

It has long been recognized that history is a strategic resource. From as early as the first discussions of the resource-based view of the firm ${ }^{24}$, there has been the recognition that history can strategically advantage firms. There is, however, disagreement about why history is a resource. One approach sees history, and the value it provides, as resulting from the unique and specific paths taken by the organization. The experiences gained from travelling these paths, when accumulated, create causal ambiguity around why firms do things the way that they do. The past of the organization is considered an indelible piece of its identity —in many cases forming the backbone of the corporate DNA or organizational culture. An organization's history is grounded in the facts of the past and, as such, it can be a source of great strength or, conversely, an impediment to the organization ${ }^{25}$. As a result, the firm is either trapped or advantaged by the deeds of past managers and the luck of the draw, which is usually of great significance to the organization and how it operates ${ }^{26}$.

Furthermore, these distinct paths confer an advantage on firms because they create resource heterogeneity. Events happen to the organization and these are passively accumulated and aggregated into 'the past ${ }^{27}$. As organizations develop and mature they acquire different resources that can be protected and leveraged. The possession of different resources makes available many alternative choices and permits managers to make different decisions and to take different strategic actions. The past is merely another "'object' of the

organization" 28 that can be collected and stored. When a firm's history is understood as an object, managers are put in a position where they are compelled and limited by the 
historical trajectory of the organization. They are expected to make strategic decisions on the basis of the paths the organization has travelled and the assets it has accumulated. In other words, history is an organizational resource because of past experience and asset accumulation.

Although the view of history as object is a popular approach in strategy and organization theory, some scholars have called into question the contention that history is an object of the organization ${ }^{29}$. In contrast, history can be understood as knowledge that is collected and meaningfully interpreted about what happened in the past ${ }^{30}$. How the historical knowledge of an organization is reconciled, presented, and discussed then becomes the focus of a manager and not the event itself. The emphasis is on the 'packaging' of the organizational past and its significance for a specific set of stakeholders ${ }^{31}$. This epistemological position explores how history is built, constructed, and conveyed to those both inside and outside the organization ${ }^{32}$ as well as how knowledge is collected, and then deployed. ${ }^{33}$ The implication is that history is not something that organizations accumulate; it is a process that managers control and shape. Managers are able to shape the past of the organization to meet its current and future needs ${ }^{34}$. The source of the firm's competitive advantage rests in the causal ambiguity around the processes that managers use to collect, interpret and disseminate knowledge about the organization's past. Moreover, through this process managers construct histories that are unique to the organization.

The aforementioned distinction relating to history is fundamental to the study of history as a resource. If history is a mere product of historical circumstances then history acts only a catalyst to enhance (or diminish) other organization assets (e.g., location, learning, alliances). In contrast, if history is malleable and the product of managerial skill in 
producing knowledge about the past, then history can be used strategically to meet the needs of specific organizational goals in particular situations.

Yet, if history is a resource produced by a process of developing knowledge of the past, how this knowledge is strategically developed needs further explication. We argue that history is produced in and through narratives of the past. Theses narratives are developed to cope with change and uncertainty ${ }^{35}$ as well as stability and continuity. As such, this makes them particularly valuable tools for managers to use to achieve their goals. Nevertheless, why this is done and when this occurs is still opaque. There is some understanding about why managers leverage their historical narratives and there is some recognition that the use of history varies by situation and circumstance ${ }^{36}$. What is missing, however, is a nuanced discussion about why managers build and use historical narratives and the different circumstances when different narratives are used. In the following sections we explore these two questions.

\section{Construction of historical narratives}

History is one of those words that encompasses different meanings within different communities $^{37}$. Mainstream organization theory has traditionally conflated history with the past and has focused on the influence past events and situations have on organizations. Business history, in contradistinction, is generally understood as the work of a professional historian or as the output of historical research aimed at reconstructing the past in narrative form. The recent rapprochement between the two fields, however, provides researchers the opportunity to explore the use of historical methods to inform organizational theorizing ${ }^{38}$ and to apply theoretical concepts and frameworks to develop historical analysis ${ }^{39}$. 
A third and less developed approach has also emerged from the confluence of business history and organization theory. This approach, often called the 'uses of the past', examines how the past can be used as an organizational resource when it is historicized. In other words, research focuses on how managers and organizations interpret, appropriate, and mobilize the past through the development of historical narratives. History, from this perspective, is not something that happens to an organization; it is a narrative constructed around the past that frames the way an organization is viewed which provides guidelines about how it should be managed.

To further develop this perspective we integrate the organization studies and business history literatures to theorize about the circumstances when historical narratives are produced in organizations. We acknowledge that managers are storytellers and that the stories they generate lead to and enact important organizational outcomes. We also concur with business historians that history and the past are not the same. If we recognize that history is not a given, but is a narrative construction subject to the dynamics of cultural production, we need first to understand the factors that influence managerial interpretations of the past and the past of their companies. That is, we need to understand the different approaches managers can have toward history, to whom they direct their narratives, how they create identification amongst their audience and, finally, the different situations when strategic historical narratives are used, changed, and renewed over time.

\section{Approaches to History}

When managers develop historical narratives they can either embrace a more realist or constructivist approach to their organization's past ${ }^{40}$. An ideal-type, realist account of corporate history emphasizes that it is an 'objective' and true account of the organization's past. This realist, historical narrative is usually a 'grand history' of the corporation that is 
framed as a detailed, truthful account of who did what, when, and where in a coherent and integrated set of events. The realism of the narrative is often supported by deep archival research and the use of historical sources. Organizations can, and often do, hire professional historians to develop their realist historical narratives. The historians' knowledge of archival research, his/her ability to write an objective history, and the status of the historian as a professional helps managers argue for the truthfulness of their accounts vis-à-vis other historical narratives of the organization's past.

Another managerial approach to constructing historical narratives is more constructivist. The historical narrative is more or less open to multiple interpretations and, in some cases, is a matter of invention. An extreme version of a constructivist, historical narrative would exhibit little difference from other kinds of stories organizations tell. A more moderate view, however, recognizes that although history is constructed based on a set of sources and remains from the past, the importance and the meanings acquired by the historical sources are malleable and change over time. Each historical narrative is considered to be only one version of the past and is merely a partial account of the totality of what once occurred. Historical evidence emerges from the vested interests of the manager in telling a story and the uses s/he has for the remnants of the past.

Depending on a manager's approach to history, different sources are used to support and make sense of the story they want to convey to an audience. Historical sources tend to be more prominent and significant when organizations are concerned with the veracity and truthfulness of its account of the past. Historical sources are of lesser importance if a fabricated historical narrative has particular strategic value. Nevertheless, a historical narrative has to be "convincing and accepted" 41 if it is to have strategic value. This means that historical narratives have to be coherent (i.e., the story must make sense) and consistent 
(i.e., it must be grounded in the past) to be effective as resources ${ }^{42}$. How this happens depends greatly on how managers address the audience of the historical narrative and whether they encourage identification through similarity or difference.

\section{Strategic orientation}

Historical narratives connect the past, present, and future of an organization. Managers construct historical narratives to make sense of what was done in the past and to identify links between the past with the present. The past is a rich source of knowledge and experience that can be appropriated and recycled; but the past can also be a liability ${ }^{43}$. Moreover, the future can be experienced as the past ${ }^{44}$, and might provide important information to the development of organizational strategies aimed at avoiding harmful trajectories or achieving a desired situation in the future. As a result, the way managers see the past impacts their use of history as a valuable strategic resource ${ }^{45}$.

Managers engage with history to emphasize either continuity or change with the organization's past ${ }^{46}$. Depending on their perception of the past, managers might chose to revive and reinforce past values and behaviours, or they might prefer to break with the way things have been done and develop new practices and traditions ${ }^{47}$. When the past is seen as an impediment to the future development of the organization, historical narratives might be used to emphasize change. For instance, past managers and events might be blamed for the present situation of the company and provide an opportunity for new strategic actions and the elaboration of alternative futures ${ }^{48}$. Alternatively, when the past is seen as a source of distinctiveness and competitive advantage for the company, managers might develop historical narratives that tap into the past to provide a sense of continuity with the present ${ }^{49}$. In any case, continuity and discontinuity will never be polar opposites when writing history ${ }^{50}$. 
Managers might also choose to discontinue some practices and values and not others. In other words, history might be used to rebut certain practices and legitimate others, as well as a way to revive successful legacies from the past. As Brunninge persuasively argues, "history is used ideologically in order to explain, teach and justify the management practices that are important to the company" ${ }^{51}$. His research has shown how managers at Scania have extensively used historical examples and made references to the past of the company to justify its standalone strategy, as well as to criticize a takeover attempt from Volvo in 1999. In both situations, the case of the Italian truck maker Iveco was used as a negative example of corporate strategy, at the same time as other positive examples from history were deployed to reinforce the organic growth strategy embraced by the management team at Scania ${ }^{52}$.

Managers at Scania also skilfully used history to recover Scania's modular philosophy. The success of the modular system led to the taken-for-grantedness of the modularization philosophy by the company's employees. Over time, however, the company begun to experience quality problems as a result of the excessive focus by new employees on standardization. Managers realized that this was a consequence of the changed meanings attributed to the modular system. The solution they offered was to revive the original modularization philosophy, by producing a booklet with the history of the approach to educate new employees about this important organizational tradition.

Forgetting, instead of remembering, is another way in which the past is strategically used within organizations. Managers might emphasize a rupture with the past to welcome a new present ${ }^{53}$. For example, they might wish to forget the recent past of the company to revive its golden years ${ }^{54}$ or, alternatively, they might want to highlight continuity with recent history of the company instead of focusing on a long forgotten past. The history of 
Handelsbanken, whose history dates back to 1871 , is a company where managers and employees only reference the history of the bank from the 1970s onward, forgetting almost 100 years of the bank's past. This can be explained by the fact that in the 1970s the bank transformed its identity to emphasize the decentralization of its operations. As a result, when people make reference to the history of the company, they hardly account for the years prior to this watershed period, forgetting both good and the bad from the distant past. What this and the other examples suggest is that historical narratives can be important strategic resources for managers to leverage when contemplating strategic decisions about organizational continuity or change.

\section{Producing identification}

Historical narratives are forms of organizational rhetoric that provide accounts of the organization's past. The use of rhetoric, in the tradition of the 'old' rhetoric, was aimed at persuading a specific audience. In this sense, organizational rhetorical history was defined as "[...] the strategic use of the past as a persuasive strategy to manage key stakeholders of the firm" ${ }^{55}$. But the old rhetoric's focus on persuasion is biased towards the rhetorician and pays little attention to the audience. The 'new' rhetoric, we argue, is a stronger approach to understand how managers use historical narratives to not just persuade but to produce 'identification' ${ }^{56}$.

The rhetorical function of a historical narrative is primarily the creation of identification with a given audience. Identification - which also implies difference -, is produced through the use of history as a means of 'consubstantiating' different elements in a unit and 'distinguishing' amongst them and others ${ }^{57}$. But identification does not equal persuasion. While the old rhetoric saw persuasion as a matter of planned design, the new rhetoric considers identification as a process of co-construction. Identification with an 
organization is co-created by managers, who construct the narrative, as well as the audience who identify with the organization. Historical narratives are thus framed to enhance the identification and/or difference amongst specific audiences.

Previous research has demonstrated that historical consciousness is integral to the work of managers in organizations. Historical narratives provide a way for managers to reflect on their "[...] past activities to explain, justify and initiate new actions" ${ }^{58}$. Through history-telling, managers make sense of the past for themselves and for others ${ }^{59}$. Reinterpretation and re-signification of the corporate past turns it into a useful resource in the hands of managers to develop new strategies and build identification with internal and external audiences ${ }^{60}$. As both the previous examples of Scania and the Handelsbanken show, the historically informed management philosophies at the two companies "[...] contributed to clearly distinguishing the companies from their competitors" ${ }^{61}$. In both cases, history-telling the corporate past was a strategy for generating identification and gaining support from internal and external audiences to the strategic plans and actions intended by the organizations. Supporting strategic moves with historical narratives thus enhances the credibility of managerial claims to uniqueness, which provides a rationale for different people to identify with the organization ${ }^{62}$.

The construction of historical narratives is, therefore, a process of creating a shared collective past $^{63}$. By connecting the past, the present, and the future in a historical narrative, managers create a valuable resource that brings people together from different times and places into a coherent whole. Patterns of interlocked events converge to produce a shared state of affairs that other organizations are unable to recreate. Managers, thus, engage in the rhetorical development of historical narratives as part of their strategy making process ${ }^{64}$ by generating identification within the organization's audiences. 


\section{Audience of narrative}

A historical narrative is more than just the story the manager wants to tell. The significance and the meaningfulness of a historical narrative can only be understood by gauging the impact it has on an audience. A manager's approach to identification (i.e., difference or similarity of the organization) will depend upon the audience to which the historical narrative is addressed. We distinguish between internal and external audiences of historical narratives in organizations. Internal audiences are the internal organizational stakeholders, i.e. organizational members and people that work closely with the organization. External audiences are conceived as the various external stakeholders of the organization (e.g. clients, investors, state agencies).

The degree of malleability in historical accounts is always a subject of contestation and dispute by organizational stakeholders. Internal and external stakeholders might embrace different understandings of history and might have distinct vested interests in a particular version of the corporate past ${ }^{65}$. This might lead to stakeholders questioning the whole, or the parts, of the historical narrative. For instance, the history of the organization might be dismissed because it is only a partial account of the organizational past. Thus, historical narratives that focus only on top-managers' actions and achievements might be questioned because of the overemphasis on an ideological, managerial and/or evolutionist view of an organization's history. Much of the critique raised by feminist business history has focused on this partial, gendered view of the managerial past reproduced both by practitioners and academics ${ }^{66}$.

Stakeholders might also question a historical narrative because of inconsistencies in the plot, the characters or the theme. An organization's silence about, or rendition of, a specific event could raise questions about the actors of the story, their roles and the causes 
of specific outcomes. Some stakeholders might even demand the inclusion of specific persons and events in the historical narratives and/or might also question the tone in which a given account is framed. For example, McKenna's attempt to bring the ghost-writer back in the story is one example of historical revisionism that calls for a better understanding of the influence of a specific actor in crafting a view about the past of General Motors and the subsequent development of organizational theory ${ }^{67}$. Similarly, Bell recognizes that organizational narratives are often the source of conflict because of differing stakeholder opinions about how the past should be historicized. ${ }^{68}$ And McQuarrie's study of the World Wrestling Entertainment (WWE) emphasizes how the past can be open to public debate and interpretation $^{69}$ even when an organization takes steps to distort and hide past events from external stakeholders. That said, from a managerial perspective what is at stake is never the reality of the past in and of itself. In fact, what is at stake is the ability of the organization to generate identification by aligning the knowledge of its audiences with their expectations of the past.

Summary

The preceding discussion has sketched the main characteristics of organizational historical narratives. As such, we identified some of the aspects leading to the creation of historical knowledge through narratives. First, managers can approach history from a more realist (i.e., as a narrative that mirrors the past) or more constructivist (i.e., as narrative that interprets the past from the perspective of the present) stance. The way mangers approach history will affect how they choose to construct their historical narratives.

Second, the way managers perceive the past also influences the narratives they create. The past provides the grounds for different strategic orientations, working as a source for change or continuity with a given state of affairs. Third, historical narratives are 
valuable because they produce identification. Managers use history to emphasize organizational similarity or difference with a given set of categorical attributes and the expectations of different organizational stakeholders. Finally, managers and stakeholders are recognized as co-producers of organizational historical narratives. Internal and external audiences have a voice in the construction of organizational historical narratives and these voices can be used to question and, in some cases, disrupt the story the organization wants to tell.

\section{Outcomes of historical narratives}

The discussion that follows is an attempt to further open the black box ${ }^{70}$ of how historical narratives might be used as strategic tools to achieve specific organizational outcomes. We draw on the existing, albeit scant, literature about organizational historical narratives to theorize about how the manager's goal of producing identification in different audiences is affected by the strategic use of historical narratives. Our discussion of the different conditions when this occurs will demonstrate not only why historical narratives are valuable but also how managers use them. In Figure 1 we present a typology of the four main outcomes that might be achieved through the strategic use of historical narratives in organizations.

\section{Insert Figure 1 here}

Our position is that managers use historical narratives to achieve four main goals. Narratives of an organization's past can be used to build identity, create culture, promote 
legitimacy, and generate authenticity. Managers build identity by developing historical narratives that highlight the uniqueness of the organization for internal audiences. These historical narratives emphasize the distinctive and constitutive factors that make the organization different from all others and the features that underline the superiority of its practices in relation to other organizations. But managers can also use historical narratives to build organizational culture and to promote the spread and reproducibility of internally desired behaviours (e. g. promoting commitment, motivating employees and strengthening the organization's culture and values). When the historical narrative is internally focused and the emphasis is on similarity, the outcome is the production of a corporate culture that provides a sense of permanence, belonging, and transcendence.

When the strategic objective is organizational legitimacy, managers will develop historical narratives that emphasize the similarity of the organization to a given set of standards and expectations of audiences external to the boundaries of the firm. The intention is to produce a historical narrative that demonstrates how the organization fits into the organizational field or industry by adhering to its main institutional logics and rules. In a different fashion, when the main purpose is to create authenticity, the historical narratives will still focus on a message to external stakeholders, but in this case it will emphasize the uniqueness of the organization vis-à-vis other organizations in the field. That is, the goal is to distinguish the organization and its products from others based on an argument about their distinctive origins, their intrinsic qualities, and their particular connection to a set of social values and expectations. In the sections below we discuss, in detail, these historical narratives and how they are used to achieve each different outcome.

\section{Organizational Identity}


Historical narratives are a key component of the process organizational identity construction $^{71}$. Managers use narratives about the past to create coherence within the organization $^{72}$. To do so they need to create or revise their historical narratives so that they are aligned with the expectations of their audiences and their desired future identities ${ }^{73}$. Additionally, organizations make sense of their future by thinking in future perfect tense ${ }^{74}$. They creatively construct their desired future identities by looking at the future as something that has already happened, i.e. as the past. Organizations thus present specific historical narratives to connect the organization's past, present and future identity ${ }^{75}$. In other words, historical narratives are valuable for the creation of organizational identity because they can be leveraged to explain how the organization maintained, regained or recovered its character ${ }^{76}$, how the identity of the organization has been nurtured over time and how it should be developed so the organization might achieve its future goal(s).

The work of Anteby and Molnár demonstrates how the Société Nationale d'Études et de Construction de Moteurs d'Aviation (Snecma) - a French aviation company - was successfully able to maintain one important trace of its identity by carefully editing the main narrative about the corporation's past ${ }^{77}$. Snecma's identity has always been linked to a patriotic national discourse. The company, previously known as Gnome et Rhône, was nationalized after WWII because of its unpatriotic, wartime behaviour. Thus, from inception, Snecma was "saddled... with a heavy onus of proof of patriotism" ${ }^{78}$. This unique feature of its creation, the link between the organization and a national project of development, has been constantly reemphasized and reinforced through organizational history-telling. History became even more important when the connection between the organization's identity and French nationalism was threatened by the contradiction between 
its corporate ideology and its practices. By systematically omitting historical characters and information about the past as well as framing past organizational events in a more positive light, managers were able to maintain the nationalistic claims as an integral part of Snecma's organizational identity.

The findings from Anteby and Molnár emerged from a comparison of the collective memory of Snecma's employees and the company's reports and bulletins. This comparison fueled their argument that "contradictory elements of Snecma's past were mainly left out from the firm's ongoing rhetorical history ${ }^{79}$. They identified two main mechanisms used to shape the historical narratives to reinforce Snecma's Frenchness. The first was the use of 'structural omissions'. The official historical narrative of the company was constructed to deliberately omit some important events related to the company's past. These omissions from the company's historical narrative were used to hide key aspects of its history that, if uncovered, could have undermined its claim as a French organization. The second was 'preemptive neutralization', or the attempt to neutralize the negative effects of contradictory situations in the company's past. The managers of the organization created historical narratives that focused upon the company's values. The company was thus able to produce an enduring organizational identity strongly linked with French national identity by presenting a historical narrative that repeatedly diminished or muted the influence of foreign workers and scientists. Except for the memory shared by the old former employees of the organization, this foreign side of the corporate past was completely unknown to internal stakeholders as a result of the strategic forgetting activities of the organization. The company's historical narratives de-emphasized the importance of the foreign workers and reinforced the similarities shared by the French workers thus marking the company as 
unique in the industry. In so doing, the official historical narrative was leveraged as a resource to strengthen the organization's identity and its position as one of the pre-eminent "French" corporations in France.

Historical narratives can also be used to promote or facilitate organizational identity change. In their study of organizational identity change at the LEGO Group, Schultz and Hernes ${ }^{80}$ identified the importance of leveraging corporate history to articulate a future view of the organization's identity. They argued that organizational identity reconstruction is intrinsically connected to the revision and evocation of the past and that rediscovering the corporate past has a major influence on the future identity claims of the organization. Thus, the broader, the longer, and the deeper the memory of an organization about its past, the more opportunities it will have to rework its past to provide an adequate basis for action in the present to sustain the organization's plans for the future. The managers at LEGO were able to reinterpret the past by managing the company's historical assets and identifying a common historical past that differentiated and distinguished the organization. This active reinterpretation of the company's history produced a new, encompassing historical narrative that oriented the company's strategy to support the implementation of a newly recreated historical legacy of the organization. This research thus shows how managers might skilfully appropriate some unique features of the organization's past to build distinctiveness and pride in the eyes of the employees while reinforcing the claims that differentiate the organization in the present and to pave a way for the company into the future.

\section{Authenticity}

Authenticity, in our framework, is the counterpart to historical narratives aimed at producing identity. Similar to identity, authenticity is also a claim that can be accepted or 
rejected by an audience ${ }^{81}$. But while the identity of the organization is built internally in connection with the employees and other internal stakeholders, authenticity is a form of impression management that focuses on the development of a unique image of the organization and its products for external audiences ${ }^{82}$. The use of historical narratives with a focus on authenticity is likely to occur when an organization wants to develop claims about the uniqueness of its brands or products to external stakeholders. This will mostly happen in industries where the products or services are relatively undifferentiated (e.g., financial services, cultural and creative industries $)^{83}$. Because it is difficult for customers to distinguish between the offerings of many organizations such as banks ${ }^{84}$, coffee companies $^{85}$ or distilleries ${ }^{86}$, presenting a compelling account of history that enhances an organization's authenticity is one way to build in difference from other companies in the same industry.

Historical narratives are particularly useful at creating and reinforcing idiosyncratic authenticity defined as "the unique and often quirky aspects and history of an object to make it seem authentic" 87 . Idiosyncratic authenticity is particularly effective when the unique and historical aspects of organizations are used to demonstrate organizational difference. This difference is reinforced and expressed through narratives that explain how historical features contribute to the organization's differentiation from other, like entities. As these historical narratives become more accepted they also become taken-for-granted and appeal to "a collective past, a link between modern society and an earlier social body" 88 that customers and clients embrace and promote as a true representation of a particular form. The customers of these organizations "know these stories and use them to motivate and justify visits and purchases; they also repeat them to friends and to others when they 
frequent the establishments or describe the products" $" 89$. When these historical narratives become taken-for-granted they become an essential, strategic component of demonstrating the distinctiveness of the organization to external stakeholders.

Jack Daniel's is one example where historical narratives have been used strategically to emphasize the idiosyncratic authenticity of a brand. In his work on iconic brands, Holt ${ }^{90}$ uncovers the taken-for-granted connection between Jack Daniel's and the historical conceptions of the frontier and the myth of the gunfighter. His historical research describes Jack Daniel's as a small company with little importance prior to the beginning of the $20^{\text {th }}$ century. Its prominence would rise only in the end of $1930 \mathrm{~s}$, when it became one of the only two Tennessee distilleries that relaunched after Prohibition. The early marketing efforts were based on existing liquor conventions and attempted to advertise Jack Daniel's as a luxury whiskey for upper-middle-class men. However, the company shifted its marketing focus after a serendipitous media campaign highlighted the connection between its product and the origins of the company. Jack Daniel's further distinguished itself from other products by inventing, emphasizing and cultivating an association between its brand, the military, masculinity, and the frontier. ${ }^{91}$. Through well-developed historical narratives, expressed through national and international marketing campaigns, Jack Daniel's has become an iconic, authentic symbol of the cowboy and rural America. Moreover, because the connection between past historical narratives and the company are taken-for-granted, the company and the brand are seen as unique, authentic producers of American whiskey for a broad base of national and international customers.

The association between Tim Horton's, Canada's largest Quick Serve Restaurant, and Canadian hockey is another example of an organization that has used historical 
narratives to imbue itself with idiosyncratic authenticity ${ }^{92}$ as a means of strategically demonstrating its uniqueness for, specifically, Canadian consumers. Through the appropriation of an existing tacit historical connection between the organization's beginnings and the founder's involvement with professional hockey in Canada, Tim Horton's has explored and reinforced a connection between the company and the country in the Canadian collective memory. In the public's eye Tim Horton's is an authentic Canadian company intrinsically linked to hockey, the country's national sport. The historical narrative linking Tim Horton's with hockey has proven to be a fruitful way demonstrating that the company is a "real" Canadian company. The company has purposefully attached itself to the collective memory of its external audience members by fostering a connection between Canadian hockey and the company's brand. As a result, the company has developed a meaningful way to differentiate itself from other fast-food companies in the industry by emphasizing its long-lasting connection with Canadian society and its preferred sport.

Another example of authenticity being produced through historical narratives is visible at Danish/Swedish dairy cooperative Arla. However, in this instance, the perception of the organization's authenticity ${ }^{93}$ was disrupted by the emergence of a counter-narrative that criticized cooperatives for being undemocratic, monopolistic, and multinational. In the eyes of the Danish public, Arla's success and position as the industry leader meant that the company no longer fit within the category of a cooperative. The result was that the company was criticized for being inauthentic because the company was perceived as "an (im)moral ideological actor that has betrayed its own historical origins as well as the Danish nation"94. In contrast, customers outside of Denmark, where people do not share the 
same historical and ideological background about cooperatives, Arla continues to be seen as a successful, authentic business. The historical narratives of the company and its association with the cooperative movement have now become a source of liability to Arla's image within Denmark. The organization now faces a situation where the firm's history as the leading the Danish/Swedish cooperative is not a source of distinctiveness and pride. Instead, the firm's historical narrative is, in fact, a liability, because the audience no longer recognizes Arla as a cooperative but as another large global corporation.

\section{Legitimacy}

Organizations can build legitimacy by creating an appealing narrative of the past. The use of historically grounded arguments to generate legitimacy is an integral part of theorizations of change in many levels of analysis ${ }^{95}$. Historical narratives can legitimate organizations by making reference to important signifiers appropriated from a community's past $^{96}$. For example, the nation is a unit from which past objects, such as important events and cultural symbols, can be appropriated to provide legitimacy to the organization and the actions of managers ${ }^{97}$. An extreme case of appropriation occurs when the presented historical narrative lacks any direct connection to the organization. This is a relatively rare occurrence because of the need for the historical narratives to resonate with the stakeholders of the organization $^{98}$. And, although historical narratives are unlikely to completely rely on appropriated objects, it is not out of the realm of possibility.

The use of historical narratives to build legitimacy is most likely to occur in two situations. The first is when organizations or some of its practices are new and lack a past

of their own ${ }^{99}$. Without a past, the organization lacks any symbolic markers of legitimacy related to an industry and a set of stakeholders. Furthermore, without a past it can be 
difficult to set a course for future action. In this case, organizations might use historical narratives to construct a story about the past by borrowing building blocks from the past of another organization or institution. Thus some organizations might be successful at legitimating themselves by constructing historical narratives that reference specific rules, values, and practices that were borrowed from foreign field(s) or organization(s).

Research on the introduction of new technologies and new market categories provide examples of the importance of referencing historical narratives to bringing about legitimate change. For instance, Hargadon \& Douglas (2001) use Thomas Edison's design of the electrical system to explain why it is strategically important to pay attention to past institutional grammars. The authors describe how Edison's strategy for legitimating the electric light was based on mimicking the familiar design taken from the gas system. By cloaking his system with pre-existing schemes and scripts from the past gas system, Edison referenced past cultural symbols and created new historical narratives to make sense of and introduce new products and ideas. The legitimacy of new innovations and organizations can be thus created through historical narratives that frame theses novelties using familiar cues and knowledge from the past. The new electric lightning system tapped into some design skeuomorphs ${ }^{100}$, previously recognized historical design features known to the audience, as a way of signalling similarity with the existing gas system and thus legitimating the changes to a new technology. By framing the unknown system on familiar historical cues, Edison was able to appropriate the legitimacy of the existing system and extend it to the new electric light.

Organizations and/or groups also construct historical narratives to create and maintain legitimacy when their previous activities can be questioned and seen as 
illegitimate. Taylor and Freer's critical analysis of the politics of remembering America's nuclear past demonstrates how the production of history is attached to a political and rhetorical process where different actors might impose their own preferred narratives ${ }^{101}$. This is especially true for businesses and industries highly sensitive to public opinion, as is the case of military and nuclear industries. The authors focus on the conflicting views between 'objective' organizational professionals and 'interpretivist' academic historians about the Hanford Site Historic District plutonium facilities. Looking at the production of history as an exercise of performative rhetoric and a site for ideological battles, Taylor and Freer demonstrate "how the struggle to maintain corporate hegemony is conducted through the production and reception of historical discourse" ${ }^{102}$. They demonstrate that historytelling by the Hanford professionals was fundamental to support the continued existence of the organization and its memorable past. Thus, by developing a number of narratives the professionals at Hanford were able to neutralize negative critiques by attaching the corporate practices to a different historical mind-set, minimizing the agency of corporate actors, deemphasizing the negative consequences of its actions, and disseminating a depoliticized and objective view of the corporate past. And although the organization was unable to escape the criticism of academic stakeholders, the organization's historical narratives were powerful enough to preserve the legitimacy of the organization and its past actions in the eyes of other external audiences.

In other cases, the collective past of a group of organizational actors is so tarnished that, as a group, they strategically collaborate in an attempt to enhance their legitimacy within specific communities. To do so, they create a compelling historical account about their collective practices and products by drawing on past objects from nation states and 
other social entities. Hills, Voronov \& Hinings found that the need for legitimacy in the Ontario wine industry necessitated the creation and appropriation of new historical narratives to overcome the perception that Ontario wines were of inferior quality. They argue that the wine makers of the region used rhetorical history to overcome a stigmatized past to construct a new, borrowed, historical narrative that legitimated the entire strategic group $^{103}$. The Ontario wine industry was able to re-invent itself based on a new institutional logic that the members of the industry developed by tapping into the global history of fine winemaking. Specifically, the wineries legitimated themselves by constructing narratives that emphasized their historical attachment to worldwide standards while, simultaneously, dismissing the stigmatized history of Ontario's wine production. By appropriating historical narratives about European winemaking, Ontario wine producers' constructed their own historical narratives that legitimated their place in the global market while de-emphasizing their unflattering past. Through this strategic process of forgetting an unflattering side of their histories and praising the values of a European winemaking heritage, Ontario wineries successfully legitimated themselves and their products to Canadian customers, and were also able to gather recognition and approval in new international markets.

\section{Organizational Culture}

Organizations can change or maintain their cultures by enhancing and developing historical narratives. Historical narratives resonate within organizations precisely because they are

developed to further enhance or to change the espoused values of the organization ${ }^{104}$. When historical narratives are constructed and then deployed the predominant aim, in this instance, is to infuse or re-infuse the organization with a set of values that are obvious and easily identifiable. The historical accounts that are told about the organization are 
deliberately constructed to emphasize what it means to be part of a particular company, group or division ${ }^{105}$. Moreover, such an impression of organizational history is constructed to emphasize or reinforce specific values that are important to the organization in the present ${ }^{106}$. These may stay constant for many years or these values may change quickly. The main point is that when historical narratives are publicized they act as a mirror that reflects back the current values of the organization.

The culture of Cadbury was created through a skilful process of historical association with Quaker traditions ${ }^{107}$. Over time, the connections between the company and Quakerism became a source of competitive advantage to the organization, which reinforced the historical narrative around the origin and importance of the company's values. Rowlinson and Hassard reconstruct the historical process of organizational culture creation by demonstrating how managers selected specific characters and events that were best suited for inventing a corporate culture around Quakerism. Strategically connecting the organization's values to a set of religious values through historical narratives provided a strong and stable base around which the corporate culture could be developed. The corporation embodied this specific set of religious values and established a foundation for an enduring culture among internal stakeholders. At the same time, by sending a message about the similarity between the values espoused by the corporation and the religious values embraced by the Quakers, Cadbury opened new avenues to encourage their employees to connect with the company that signalled consistency and coherence over time.

The effortless association between inherited historical narratives and the new organizational myths and values managers want to inscribe in the corporate culture is not 
always evident or easy. As Hansen argues in his study of Danish savings banks, historical narratives embedded in an organization's culture might be valuable resources as well as constraints for the organization. As long as the main cultural narrative of the organization remains unchallenged by external pressures, the organization's culture should remain a strong, integrated ideological unit and, thus, a resource for the organization. But, as soon as external parties start questioning the historical narratives of the organization, its culture can become differentiated or fragmented among internal stakeholders. This process occurred and was exacerbated in the case of the Danish savings banks. The banks' historical narratives became embodied in the Danish imaginary, which limited the banks' ability to control their shared views about past values and traditions. Changes in the master narratives of Danish society during the 1960s and 1970s became sources of pressure on the democratic, cooperative, mutualistic, and not-for-profit values espoused in the savings banks' historical narratives. This cultural shock fostered the emergence of new narratives about the past. These new narratives facilitated the disintegration and fragmentation of the saving banks' integrated culture, which could be seen in the progressive emergence of a diverse organizational narratives, values, and goals. Hansen's analysis thus demonstrates how the cultural heritage of the Danish savings bank movement was reworked, resignified, and repurposed when exposed to competing institutional rationales, and how this has helped them to loosen the cuffs of their path dependence and afforded them the possibility of developing practices usually associated with commercial banks.

\section{Discussion}

The argument advanced in this paper is that historical narratives are resources managers use to achieve specific organizational goals. History, we argue, is a form of organizational 
knowledge created though narratives of the past. Managers develop historical narratives to produce identification with internal and external audiences. They emphasize similarity to internal audiences when the desired outcome is creating organizational culture, and distinctiveness when the focus is on building identity. Likewise, when external audiences are addressed and the intended outcome is generating legitimacy managers will tell a history of similarity and to build authenticity managers will focus on a history of distinctiveness. Our analysis of the strategic uses of historical narratives is, thus, a first step in developing a more complex and nuanced comprehension of how historical narratives operate as valuable organizational resources.

Our discussion of the strategic uses of historical narratives makes a number of contributions to our understandings of both organizational history and organizational theory. First, we posit that history can be approached from a realist or constructivist perspective and, because of this, different managers tell different narratives about the organization's past. Also, historical narratives will be produced within the depending on the strategic purposes and challenges faced by managers. In any case, this understanding should help managers recognize that historical narratives are malleable strategic resources that, when properly leveraged, can deliver value to the firm.

Our work also calls attention to managerial reflexivity and organizational history. The ability to identify different circumstances when history is presented in one's organization can lead to changes in how historical knowledge is created, discussed, and presented to better serve the strategic purposes of the organization ${ }^{108}$. We have shown that historical narratives are more than just inert stories that organizations tell about the past. They are important organizational resources that can be strategically mobilized to 
accomplish corporate goals. The way the story of an organization's past is told will influence what the organization can do, how it can be done, and who will be involved with the organization in the future. Managers can identify different ways to build new historical narratives and to enhance current, effective organizational history-telling practices. Our work also points to ways that different groups can disrupt long-standing and taken-forgranted historical narratives. Managers that recognize the different historical narratives told in their organizations can possibly take actions to create fertile situations where a particular form of historical narrative is welcome or where a form of historical narrative needs to be discouraged or eliminated.

Another contribution of our work has been to identify different outcomes that managers can address with historical narratives. These four outcomes are some of the important and common goals that managers strive for when leveraging their historical narratives. Nevertheless, it would be imprudent if we were to suggest that our discussion is exhaustive. What we have outlined is a preliminary, theoretical exploration of the different ways that historical narratives have been used strategically. The typology presented is intended to be a starting point for further discussions about the circumstances and the reasons why managers construct and use history to achieve the organization's strategic goals. Future investigations would contribute to this stream of research by analysing how organisations pursue these four outcomes together or separately. It would be interesting to analyse if multiple historical narratives in organisations are coherent and how a sense of cohesiveness is achieved by managers through the (re)interpretation and skilful appropriation of past histories and (re)creation of the narratives of the organizational past. 
Although our focus has been predominantly on the outcomes managers can achieve through the strategic use of historical narratives, we would be remiss if we did not mention that historical narratives also have the potential to be sources of organizational liabilities. There are two main cases when this might happens. The first is when negative past associations between an organization and its members/products are rediscovered and re-emerge as negative accounts of the corporate past. The discovery of "skeletons" in the corporate closet can create a great inconvenience for the company. These new discoveries could potentially be used to disparage the company to both internal and external audiences thus undermining the image and reputation of the organization. ${ }^{109}$ A second instance where historical narratives can become liabilities occurs when historical narratives loose flexibility and create self-reinforcing mechanisms that lessen the organizational performance and lead to organizational inertia ${ }^{110}$. When historical narratives become institutionalized ${ }^{111}$ and are taken-for-granted it is harder for managers to change them to adapt to new organizational realities. Both instances suggest that while managers attempt to control historical narratives, they are not able to control them in their totality. Historical narratives and most common interpretations of these stories will always be more or less open to counterhistorical narratives ${ }^{112}$. So, in contrast to official, managerial historical narratives, ample space exists for other groups, internal and external to the company, to make sense of the organizational past and to create alternative historical narratives ${ }^{113}$.

These aforementioned points emphasize that historical narratives are co-constructed between managers the organization's stakeholders. We see an organization's historical narrative as only one version of the past and this version is always subject to critique and contestation. In fact, there is often a great deal of negotiation between managers and their 
audiences towards the way a narrative should be written and the meaning that should be attributed to the story ${ }^{114}$. We argue that there is nothing definitive about a manager's version of the corporate past, a position that puts us at odds with the existing literature on the ability of managers to use history for ideological purposes ${ }^{115}$. Thus, historical narratives, despite the promise and strategic value that they provide, are merely tools to be used by both managers and their audiences for different purposes. And these tools are best developed by skillful managers who understand that there can be many available versions of an organization's past and that the strategic value of historical narratives depends on their ability to create a particular version of the past that fosters identification within an intended internal or external audience.

\section{Conclusion}

Our theoretical approach marks a departure from traditional, historically informed organizational theory and pre-linguistic turn business history. Instead, our focus has been on the managerial use of historical narratives. And, while much research has focused on history as an explanatory variable or a source for research methods, our discussion explained why historical narratives could be viewed as organizational resources. Although this is a different analytical lens from business historians and organizational theorists, we argue that it is important to recognize that some managers might also be skillful historians of the corporate past and that this skill can be an important used to achieve the strategic goals of organizations. Moreover, our discussion also indicates that a focus on the uses of the past in corporate settings is an opportunity for business historians to explore other, existing genres of narratives about the past. Thus, we have argued against a view of history as something that happens to an organization. We have also rejected the idea that history is 
the exclusive output of the work of professional historians. Instead, we have argued that history is strategically created and recreated by managers in organizations. Our goal has been to enhance our understanding of how historical narratives are used strategically as organizational resources. In so doing we hope to open new avenues for research that can further extend the current integration between business history and organization theory. 


\section{Bibliography}

Adorisio, Anna Linda Musacchio. "Organizational Remembering as Narrative: 'Storying' the Past in Banking." Organization 21, no. 4 (2014): 463-76.

Albert, Stuart, and David A. Whetten. "Organizational Identity." In Research in Organizational Behavior, edited by Larry L. Cummings and Barry M. Staw, 26395. Greenwich, CT: JAI Press, 1985.

Anteby, Michel, and Virág Molnár. "Collective Memory Meets Organizational Identity: Remembering to Forget in a Firm's Rhetorical History." Academy of Management Journal 55, no. 3 (June 1, 2012 2012): 515-40.

Barney, Jay B. "Strategic Factor Markets: Expectations, Luck, and Business Strategy". Management Science 32, no. 10 (October 1, 1986): 1231-41.

Barney, Jay B. "Firm Resources and Sustained Competitive Advantage." Journal of Management 17, no. 1 (1991): 99-120.

Barney, Jay B. "Is the Resource-Based 'View' a Useful Perspective for Strategic Management Research? Yes". The Academy of Management Review 26, no. 1 (January 1, 2001): 41-56.

Bell, Emma. "Ways of Seeing Organisational Death: A Critical Semiotic Analysis of Organisational Memorialisation." Visual Studies 27, no. 1 (2012/03/01 2012): 4-17.

Beverland, Michael B. "Crafting Brand Authenticity: The Case of Luxury Wines." Journal of Management Studies 42, no. 5 (2005): 1003-29.

Booth, Charles, Peter Clark, Agnes Delahaye, Stephen Procter, and Michael Rowlinson. "Accounting for the Dark Side of Corporate History: Organizational Culture Perspectives and the Bertelsmann Case." Critical Perspectives on Accounting 18, no. 6 (2007): 625-44.

Brown, A. D., and M. Humphreys. "Nostalgia and the Narrativization of Identity: A Turkish Case Study." British Journal of Management 13, no. 2 (2002): 141-59.

Brunninge, Olof. "Using History in Organizations: How Managers Make Purposeful Reference to History in Strategy Processes." Journal of Organizational Change Management 22, no. 1 (2009): 8-26.

Burke, Kenneth. A Rhetoric of Motives. Berkley: University of California Press, 1950.

Carr, Edward Hallett. What Is History? The George Macaulay Trevelyan Lectures. London: Macmillan, 1961.

Carroll, C. E. "Introduction: The Strategic Use of the Past and Future in Organizational Change." Journal of Organizational Change Management 15, no. 6 (// 2002): 55662.

Carstairs, Catherine. ""Roots" Nationalism: Branding English Canada Cool in the 1980s and 1990s." Social History/Histoire Sociale 39, no. 77 (2006): 235-55.

Chreim, Samia. "The Continuity-Change Duality in Narrative Texts of Organizational Identity." Journal of Management Studies 42, no. 3 (2005): 567-93

Collingwood, R. G. The Idea of History. A Galaxy Book. New York: Oxford University Press, 1956.

Collins, Jim, and Jerry I. Porras. Built to Last: Successful Habits of Visionary Companies. New York: HarperCollins, 2005.

Connerton, Paul. How Societies Remember. Cambridge: Cambridge University Press, 1989. 
Coraiola, Diego M, William M Foster, and Roy Suddaby. "Varieties of History in Organization Studies." In The Routledge Companion to Management and Organizational History, Routledge, 206-21. New York: Routledge, 2015.

Craig, Béatrice. "Petites Bourgeoises and Penny Capitalists: Women in Retail in the Lille Area During the Nineteenth Century." Enterprise \& Society 2, no. 02 (2001): 198224.

Cutcher, Leane. "Creating Something: Using Nostalgia to Build a Branch Network." Journal of Consumer Culture 8, no. 3 (2008): 369-87.

Dalpiaz, E., V. P. Rindova, and D. Ravasi. "Where Strategy Meets Culture: The Neglected Role of Cultural and Symbolic Resources in Strategy Research." 27, (2010): 175208.

David, Paul A. "Clio and the Economics of Qwerty." The American Economic Review 75, no. 2 (1985): 332-37.

Dawson, Patrick, and Peter McLean. "Miners' Tales: Stories and the Storying Process for Understanding the Collective Sensemaking of Employees During Contested Change." Group \& Organization Management 38, no. 2 (April 1, 2013 2013): 198229.

Decker, Stephanie. "Solid Intentions: An Archival Ethnography of Corporate Architecture and Organizational Remembering." Organization 21, no. 4 (July 1, 2014 2014): 514-42.

Deephouse, David L. "To Be Different, or to Be the Same? It's a Question (and Theory) of Strategic Balance.". Strategic Management Journal 20 (1999): 147-66.

Delahaye, Agnès, Charles Booth, Peter Clark, Stephen Procter, and Michael Rowlinson. "The Genre of Corporate History." Journal of Organizational Change Management 22, no. 1 (2009): 27-48.

Durepos, Gabrielle, Albert J. Mills, and Jean Helms Mills. "Tales in the Manufacture of Knowledge: Writing a Company History of Pan American World Airways." Management \& Organizational History 3, no. 1 (February 1, 2008 2008): 63-80.

Durepos, Gabrielle, and Albert J. Mills. "Actor-Network Theory, Anti-History and Critical Organizational Historiography." Organization 19, no. 6 (November 1, 2012 2012): 703-21.

Foster, William M., and Craig G. Hyatt. "Inventing Team Tradition: A Conceptual Model for the Strategic Development of Fan Nations." European Sport Management Quarterly 8, no. 3 (2008): 265-87.

Foster, William M., Roy Suddaby, Alison Minkus, and Elden Wiebe. "History as Social Memory Assets: The Example of Tim Hortons." Management \& Organizational History 6, no. 1 (2011): 101-20.

Gamber, Wendy. "A Gendered Enterprise: Placing Nineteenth-Century Businesswomen in History." The Business History Review 72, no. 2 (1998): 188-217.

Geiger, Daniel, and Elena Antonacopoulou. "Narratives and Organizational Dynamics: Exploring Blind Spots and Organizational Inertia." The Journal of Applied Behavioral Science 45, no. 3 (2009): 411-36.

Gioia, D. A., K. G. Corley, and T. Fabbri. "Revising the Past (While Thinking in the Future Perfect Tense)." Journal of Organizational Change Management 15, no. 6 (2002): 622-34.

Gioia, Dennis A., and Kumar Chittipeddi. "Sensemaking and Sensegiving in Strategic Change Initiation." Strategic Management Journal 12 (1991): 433-48. 
Hansen, Per H. "Business History: A Cultural and Narrative Approach." Business History Review 86, no. 04 (2012): 693-717.

Hearn, M. (2008). Productivity and patriotism: The management narrative of New South Wales Rail Chief Commissioner James Fraser, 1917-1929. Business History, 50(1), 26-39.

Hills, Shilo, Maxim Voronov, and C.R. Bob Hinings. "Putting New Wine in Old Bottles: Utilizing Rhetorical History to Overcome Stigma Associated with a Previously Dominant Logic." Research in the Sociology of Organizations 39 (2013): 99-137.

Maclean, Mairi, Charles Harvey, and Stewart Clegg. "Conceptualizing Historical Organization Studies." Academy of Management Review (Forthcoming).

Holt, Douglas B. How Brands Become Icons: The Principles of Cultural Branding. Harvard Business Press, 2004.

Holt, Douglas B. "Jack Daniel's America." Journal of Consumer Culture 6, no. 3 (November 1, 2006 2006): 355-77.

Janssen, Claudia I. "Corporate Historical Responsibility (Chr): Addressing a Corporate Past of Forced Labor at Volkswagen." Journal of Applied Communication Research 41, no. 1 (2012): 64-83.

Jenkins, Keith. On'what Is History?': From Carr and Elton to Rorty and White. Psychology Press, 1995.

Jones, Candace, N. Anand, and Josè Luis Alvarez. "Manufactured Authenticity and Creative Voice in Cultural Industries." Journal of Management Studies 42, no. 5 (2005): 893-99.

Jones, Geoffrey, and Jonathan Zeitlin. The Oxford Handbook of Business History. Oxford; New York: Oxford University Press, 2009.

Kaplan, Sarah, and Wanda J. Orlikowski. "Temporal Work in Strategy Making." Organization Science 24, no. 4 (2013): 965-95.

Kieser, Alfred. "Why Organization Theory Needs Historical Analyses-and How This Should Be Performed." Organization Science 5, no. 4 (November 1, 1994 1994): 608-20.

Kroeze, Ronald, and Sjoerd Keulen. "Leading a Multinational Is History in Practice: The Use of Invented Traditions and Narratives at AkzoNobel, Shell, Philips and ABN AMRO." Business History 55, no. 8 (2013): 1265-87.

Lamertz, Kai, William M Foster, Diego M Coraiola, and Jochem Kroezen. "New Identities from Remnants of the Past: An Examination of the History of Beer Brewing in Ontario and the Recent Emergence of Craft Breweries." Business History, September 7, 2015, 1-33.

Linde, Charlotte. Working the Past: Narrative and Institutional Memory. Oxford; New York: Oxford University Press, 2009.

Lipartito, Kenneth. "Culture and the Practice of Business History." Business and Economic History 24, no. 2 (1995): 1-41.

Lockett, Andy, and Andrew Wild. "Bringing History (back) into the Resource-Based View." Business History 56, no. 3 (2014): 372-90.

Maclean, Mairi, Charles Harvey, and Robert Chia. "Sensemaking, Storytelling and the Legitimization of Elite Business Careers." Human Relations 65, no. 1 (2012): 17 40. 
Maclean, Mairi, Charles Harvey, John A. A. Sillince, and Benjamin D. Golant. "Living up to the Past? Ideological Sensemaking in Organizational Transition." Organization 21, no. 4 (2014): 543-67.

Martin, Joanne, Martha S Feldman, Mary Jo Hatch, and Sim B Sitkin. "The Uniqueness Paradox in Organizational Stories." Administrative Science Quarterly (1983): 43853.

McGaughey, Sara L. "Institutional Entrepreneurship in North American Lightning Protection Standards: Rhetorical History and Unintended Consequences of Failure.". Business History (2012).

Mckenna, Christopher D. "Writing the Ghost-Writer Back In: Alfred Sloan, Alfred Chandler, John Mcdonald and the Intellectual Origins of Corporate Strategy." Management \& Organizational History 1, no. 2 (2006): 107-26.

McQuarrie, Fiona A. E. "Breaking Kayfabe: 'The History of a History' of World Wrestling Entertainment." Management \& Organizational History 1, no. 3 (August 1, 2006 2006): 227-50.

Mordhorst, Mads. "Arla and Danish National Identity - Business History as Cultural History." Business History 56, no. 1 (2014): 116-33.

Newton, Tim. "From Freemasons to the Employee: Organization, History and Subjectivity." Organization Studies 25, no. 8 (October 1, 2004): 1363-87.

Ooi, Can-Seng. "Persuasive Histories: Decentering, Recentering and the Emotional Crafting of the Past." Journal of Organizational Change Management 15, no. 6 (2002): 606-21.

Penrose, Edith. The Theory of the Growth of the Firm. New York: Oxford University Press, 1959.

Peterson, Richard A. "In Search of Authenticity." Journal of Management Studies 42, no. 5 (2005): 1083-98.

Porter, Michael E. "Clusters and the New Economics of Competition." Harvard Business Review 76, no. 6 (1998): 77-90.

Ravasi, D., \& Schultz, M. (2006). Responding to organizational identity threats: Exploring the role of organizational culture. Academy of Management Journal, 49(3), 433458.

Rowlinson, Michael, Andrea Casey, Per H. Hansen, and Albert J. Mills. "Narratives and Memory in Organizations." Organization 21, no. 4 (2014): 441-46.

Rowlinson, Michael, and John Hassard. "The Invention of Corporate Culture: A History of the Histories of Cadbury." Human Relations 46, no. 3 (1993): 299-326.

Rowlinson, Michael, and John S. Hassard. "Historical Neo-Institutionalism or NeoInstitutionalist History? Historical Research in Management and Organization Studies." Management \& Organizational History 8, no. 2 (2013): 111-26.

Rowlinson, Michael, John Hassard, and Stephanie Decker. "Research Strategies for Organizational History: A Dialogue between Historical Theory and Organization Theory." Academy of Management Review 39, no. 3 (2014): 250-74..

Rumelt, Richard P. "How Much Does Industry Matter?" Strategic Management Journal 12, no. 3 (1991): 167-85.

Saxenian, Annalee. Regional Advantage: Culture and Competition in Silicon Valley and Route 128. Cambridge, MA: Harvard University Press, 1994. 
Schneiberg, Marc. "What's on the Path? Path Dependence, Organizational Diversity and the Problem of Institutional Change in the Us Economy, 1900-1950." Socio-Economic Review 5 (2007): 47-80.

Schultz, Majken, and Tor Hernes. "A Temporal Perspective on Organizational Identity." Organization Science (May 23, 2012 2012).

Selznick, Philip. Leadership in Administration: A Sociological Interpretation. New York: Harper and Row, 1957.

Stinchcombe, Arthur L. "Social Structure and Organizations." In Handbook of Organizations, edited by James G. March, 142-93. Chicago: Rand McNally, 1965.

Suddaby, Roy, William M. Foster, and Chris Quinn Trank. "Rhetorical History as a Source of Competitive Advantage." In Advances in Strategic Management: The Globalization of Strategy Research, edited by Joel A. C. Baum and Joseph Lampel, 147-73. Bingley: Emerald, 2010.

Suddaby, Roy, William M. Foster, and Albert J. Mills. "Historical Institutionalism." In Organizations in Time: History, Theory, Methods, edited by Marcelo Bucheli and R. Daniel Wadwhani, 100-23. Oxford: Oxford University Press, 2014.

Taylor, Bryan C, and Brian Freer. "Containing the Nuclear Past: The Politics of History and Heritage at the Hanford Plutonium Works." Journal of Organizational Change Management 15, no. 6 (2002): 563-88.

Voronov, Maxim, Dirk De Clercq, and C R Hinings. "Conformity and Distinctiveness in a Global Institutional Framework: The Legitimation of Ontario Fine Wine. " Journal of Management Studies 50, no. 4 (2013): 607-45.

Weatherbee, Terrance G., Gabrielle Durepos, Albert Mills, and Jean Helms Mills. "Theorizing the Past: Critical Engagements." Management \& Organizational History 7, no. 3 (2012): 193-202.

Weick, Karl E. The Social Psychology of Organizing. Topics in Social Psychology. Reading, Mass.,: Addison-Wesley Pub. Co., 1969.

- The Social Psychology of Organizing. Topics in Social Psychology. 2d ed. Reading, Mass.: Addison-Wesley Pub. Co., 1979.

Ybema, Sierk. "Managerial Postalgia: Projecting a Golden Futurenull." Journal of Managerial Psychology 19, no. 8 (2004): 825-41.

Ybema, Sierk. "Talk of Change: Temporal Contrasts and Collective Identities." Organization Studies 31, no. 4 (2010): 481-503.

Ybema, Sierk. "The Invention of Transitions: History as a Symbolic Site for Discursive Struggles over Organizational Change." Organization 21, no. 4 (2014): 495-513.

Yeager, Mary A, ed. Women in Business. 3 vols. Cheltenham: Edward Elgar, 1999.

Zundel, Mike, Robin Holt, and Andrew Popp. "Using History in the Creation of Organizational Identity." Management \& Organizational History (2016): 1-25. 
Figure 1: Strategic uses of historical narratives

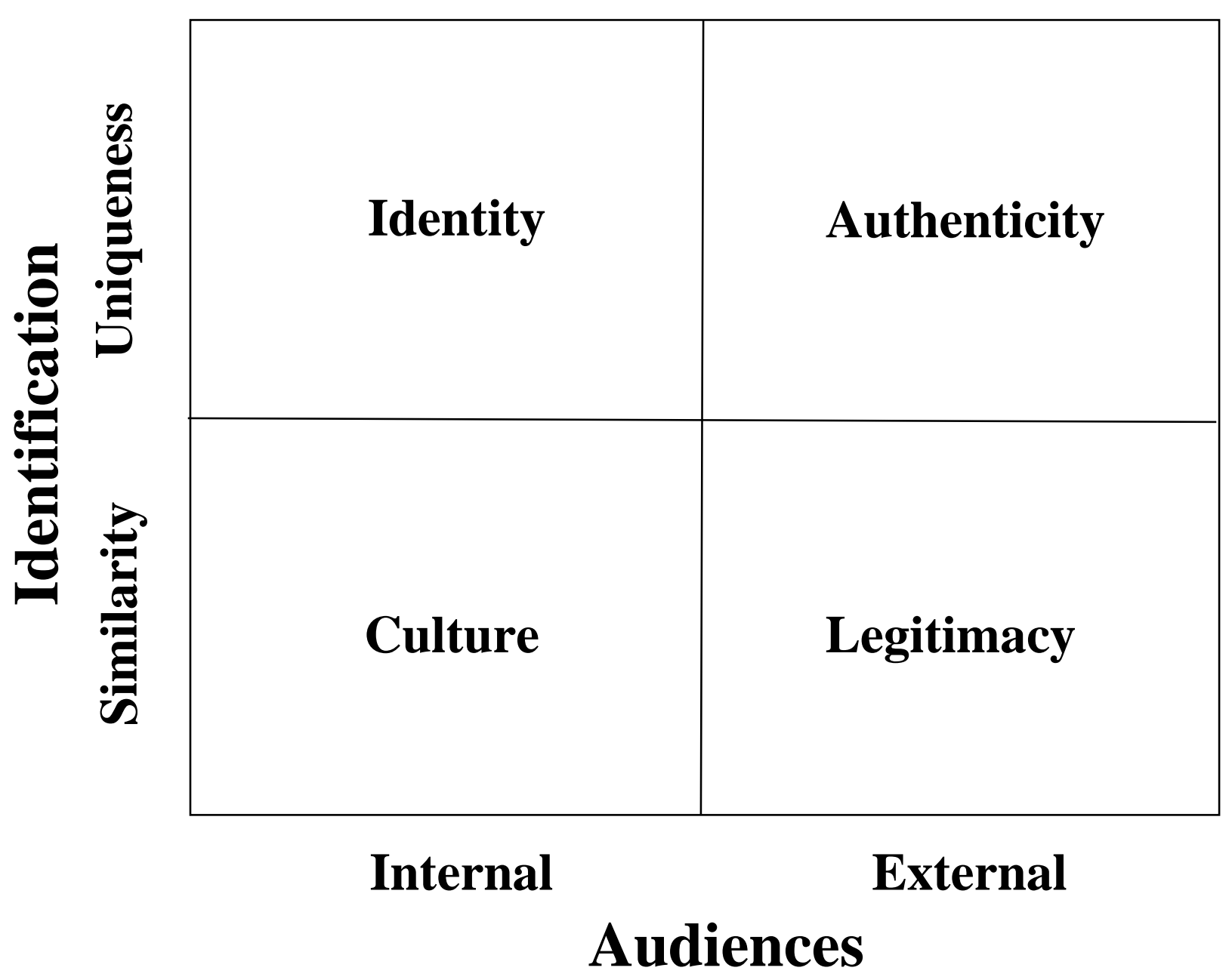


${ }^{1}$ Coraiola, Foster \& Suddaby, 'Varieties of History'; Hansen, 'Business History'; Mordhorst, 'Arla and Danish'; Rowlinson, Hassard \& Decker, 'Strategies for organizational history'.

${ }^{2}$ Jones \& Zeitlin, 'The Oxford handbook'.

${ }^{3}$ Lipartito, 'Culture and the Practice'; Hansen, 'Business History'.

${ }^{4}$ Foster et al., 'History as social memory assets'; Rowlinson et al., 'Narratives and memory'; Schneiberg, 'What's on the path?'.

${ }^{5}$ Carroll, 'Introduction'; Suddaby, Foster \& Trank, 'Rhetorical history'.

${ }^{6}$ Barney, 'Strategic Factor Markets'; Barney, 'Is the Resource-Based "View"'; Barney, 'Firm Resources and Sustained Competitive Advantage'; Rumelt, 'How Much Does Industry Matter?'.

${ }^{7}$ Porter, 'Clusters and the new economics'; Saxenian, 'Regional Advantage'.

${ }^{8}$ Maclean et al., 'Living up to the past?'; Rowlinson \& Hassard, 'The Invention of Corporate Culture'.

${ }^{9}$ Decker, 'Solid intentions'.

${ }^{10}$ McGaughey, 'Institutional entrepreneurship'; Suddaby, Foster \& Trank, 'Rhetorical history'; Ybema, 'The invention of transitions'.

${ }^{11}$ Brunninge, 'Using history in organizations'.

${ }^{12}$ Anteby \& Molnár, 'Collective Memory'.

${ }^{13}$ Suddaby, Foster \& Trank, 'Rhetorical history'.

${ }^{14}$ Lockett \& Wild, 'Bringing History (back)'.

${ }^{15}$ Adorisio, 'Organizational Remembering as Narrative'.

${ }^{16}$ Kroeze \& Keulen, 'Leading a Multinational is History in Practice'.

${ }^{17}$ Brunninge, 'Using history in organizations'; O'Connor, 'Plotting the Organization'.

${ }^{18}$ McGaughey, 'Institutional entrepreneurship'; Suddaby \& Greenwood, 'Rhetorical Strategies of Legitimacy'; Ybema, 'The invention of transitions'. 
${ }^{19}$ Rowlinson \& Hassard, 'The Invention of Corporate Culture'.

${ }^{20}$ Ibid., 15.

${ }^{21}$ Beverland, 2005, 'Crafting Brand Authenticity'.

${ }^{22}$ Ibid., 13.

${ }^{23}$ Ibid., 9.

${ }^{24}$ Lockett \& Wild, 'Bringing History (back)'; Penrose, 'The Theory of the Growth of the Firm'.

${ }^{25}$ David, 'Clio and the Economics'; Hannan \& Freeman, 'The Population Ecology'; Stinchcombe, 'Social Structure and Organizations'.

${ }^{26}$ Rowlinson, Hassard \& Decker, 'Strategies for organizational history'.

${ }^{27}$ Ibid., 9.

${ }^{28}$ Ibid., 23.

${ }^{29}$ Rowlinson, Hassard \& Decker, 'Strategies for organizational history'; Suddaby, Foster \& Trank, 'Rhetorical history'.

${ }^{30}$ Carr, 'What is history?'; Collingwood, 'The idea of history'.

${ }^{31}$ Ooi, 'Persuasive histories'.

${ }^{32}$ Anteby \& Molnár, 'Collective Memory'; Brunninge, 'Using history'; Delahaye et al, 'The genre of Corporate History'; Durepos, Mills \& Mills, 'Tales in the manufacture'; Linde, 'Working the past'.

${ }^{33}$ Booth et al., 'Accounting for the dark'; Carroll, 'Introduction'; Foster, 'History as social memory'; Gioia, Corley \& Fabbri, 'Revising the past'; Hills, Voronov \& Hinings, 'Putting new wine'; Kroeze \& Keulen, 'Leading a multinational'; Rowlinson \& Hassard, 'The Invention of Corporate Culture'.

${ }^{34}$ Linde, 'Working the past'; Zundel, Holt, \& Popp, 'Using history in the creation'.

${ }^{35}$ Ibid., 13.

${ }^{36}$ Ibid., 15. 
${ }^{37}$ Clark \& Rowlinson, 'The treatment of history'.

${ }^{38}$ Kieser, 'Why organization theory'; Harvey et al, 'Conceptualizing historical organization studies'; Suddaby et al, 'Historical institutionalism'.

${ }^{39}$ Durepos \& Mills, 'Actor-network theory'; Rowlinson \& Hassard, 'Historical neo-institutionalism'; Rowlinson et al, ' Research strategies for organizational history'.

${ }^{40}$ Jenkins, 'On what is history'.

${ }^{41}$ Ibid., 14, 1271.

${ }^{42}$ Adorisio, 'Organizational Remembering as Narrative'; Mordhorst, 'Arla and Danish'.

${ }^{43}$ Booth et al., 'Accounting for the dark'.

${ }^{44}$ Gioia, Corley \& Fabbri, 'Revising the Past'.

${ }^{45}$ Brunninge, 'Using history in organizations'; Ybema, 'Managerial Postalgia'.

${ }^{46}$ Brunninge, 'Using history in organizations'.

${ }^{47}$ Ybema, 'The invention of transitions'.

${ }^{48}$ Chreim, 'The Continuity-Change Duality'.

${ }^{49}$ O'Connor, 'Plotting the Organization'.

${ }^{50}$ Newton, 'From Freemasons to the Employee'.

${ }^{51}$ Ibid., 6, 20.

${ }^{52}$ Ibid., 6.

${ }^{53}$ Ybema. 'Managerial postalgia'.

${ }^{54}$ Brown \& Humphreys. 'Nostalgia and the Narrativization'.

${ }^{55}$ Ibid., 9, 157.

${ }^{56}$ Burke, 'A Rhetoric of Motives'.

${ }^{57}$ Ibid., 42.

${ }^{58}$ Kroeze \& Keulen, 'Leading a multinational', 1265.

${ }^{59}$ Maclean et al, 'Sensemaking, storytelling'. 
${ }^{60}$ Linde, 'Working the past'.

${ }^{61}$ Brunninge, 'Using history in organizations', 16.

${ }^{62}$ Ravasi \& Schultz, 'Responding to organizational'.

${ }^{63}$ Linde, 'Working the past'.

${ }^{64}$ Kaplan \& Orlikowski, 'Temporal Work in Strategy Making'; O'Connor, 'Plotting the Organization'.

${ }^{65}$ Bell, 'Ways of Seeing Organisational Death'; Booth et al., 'Accounting for the dark'.

${ }^{66}$ Craig, 'Petites bourgeoises and penny capitalists'; Gamber, 'A gendered enterprise'; Yeager, 'Women in business'.

${ }^{67}$ Mckenna, 'Writing the ghost-writer back in'.

${ }^{68}$ Bell, 'Ways of Seeing Organisational Death'.

${ }^{69}$ McQuarrie, 'Breaking kayfabe'.

${ }^{70}$ Durepos, Mills \& Mills, 'Tales in the manufacture'.

${ }^{71}$ Ravasi \& Schultz, 'Responding to organizational'.

${ }^{72}$ Carroll, 2002, 'Introduction'; Ybema, 'Talk of Change'.

${ }^{73}$ Carroll, 2002, 'Introduction'; Gioia \& Chittipeddi, 'Sensemaking and Sensegiving'.

${ }^{74}$ Gioia, Corley \& Fabbri, 'Revising the Past'; Weick, 'The social psychology'.

${ }^{75}$ Chreim, 'The Continuity-Change Duality'; Ybema, 'Talk of Change'.

${ }^{76}$ Selznick, 'Leadership in administration'.

${ }^{77}$ Anteby \& Molnár, 'Collective Memory'.

${ }^{78}$ Ibid., 82, 522.

${ }^{79}$ Ibid., 82, 526.

${ }^{80}$ Schultz \& Hernes, 'A Temporal Perspective'.

${ }^{81}$ Peterson, 'In search of authenticity'.

${ }^{82}$ Beverland, 'Crafting Brand Authenticity'; Carroll, 'Introduction'. 
${ }^{83}$ Dalpiaz, Rindova \& Ravasi, 'Where strategy meets'; Hills, Voronov \& Hinings, 'Putting new wine'; Jones, Anand \& Alvarez, 'Manufactured authenticity'.

${ }^{84}$ Cutcher, 'Creating something'.

${ }^{85}$ Foster et al., 'History as social memory assets'.

${ }^{86}$ Holt, 'Jack Daniel's America'.

${ }^{87}$ Carroll \& Wheaton, 'The Organizational Construction of Authenticity', 257.

${ }^{88}$ Ibid., 63, 271.

${ }^{89}$ Ibid., 63, 272.

${ }^{90}$ Holt, 'How Brands Become Icons'.

${ }^{91}$ Ibid., 62.

${ }^{92}$ Ibid., 61.

${ }^{93}$ Mordhorst, 'Arla and Danish'.

${ }^{94}$ Ibid., 104, 117

${ }^{95}$ Brunninge, 'Using history in organizations'; McGaughey, 'Institutional entrepreneurship'; Suddaby \& Greenwood, 'Rhetorical Strategies of Legitimacy'.

${ }^{96}$ Foster \& Hyatt, 'Inventing Team Tradition'.

${ }^{97}$ Carstairs, '"Roots" Nationalism'; Foster, 'History as social memory'; Hearn, 'Productivity and patriotism'.

${ }^{98}$ Ibid., 14.

${ }^{99}$ Hills, Voronov \& Hinings, 'Putting new wine'.

${ }^{100}$ The concept of skeuomorph comes from the Greek words skéuos (container, tool) and morphé (form or shape) and was coined to mean a specific kind of objects or features which were created with the purpose of mimicking the traces or characteristics of existing artefacts and elements from the past.

${ }^{101}$ Taylor \& Freer, 'Containing the nuclear past'. 
${ }^{102}$ Ibid., 116, 584.

${ }^{103}$ Ibid., 72.

${ }^{104}$ Collins \& Porras, 'Built to last'; Rowlinson \& Hassard, 'The Invention of Corporate Culture'.

${ }^{105}$ Linde, 'Working the past'.

${ }^{106}$ Gioia, Corley \& Fabbri, 'Revising the past'; Ybema, 2010.

${ }^{107}$ Ibid., 15.

${ }^{108}$ Ibid., 30.

${ }^{109}$ Ibid., 35.

${ }^{110}$ Geiger \& Antonacopoulou, 'Narratives and Organizational Dynamics'.

${ }^{111}$ Ibid., 15.

${ }^{112}$ Chreim, 'The Continuity-Change Duality'.

${ }^{113}$ Dawson \& McLean, 'Miners' Tales'.

${ }^{114}$ McGaughey, 'Institutional entrepreneurship'; Ybema, 'Talk of Change'; Ybema, 'The invention of transitions'.

${ }^{115}$ Anteby \& Molnár, 'Collective Memory'; Maclean et al., 'Living up to the past?'. 